\title{
Fossil glochidia (Bivalvia, Unionidae): identification and value in palaeoenvironmental reconstructions
}

\author{
DAVID C. ALDRIDGE \& DAVID C. HORNE \\ Department of Zoology, University of Cambridge, Downing Street, Cambridge CB2 3EJ, UK.
}

\begin{abstract}
Preserved valves of fossil glochidia have been recovered from Holocene lake marls at Quidenham Mere, UK. Detailed morphological comparisons with glochidia removed from live adult unionids have enabled confident identification of the fossil glochidia as those of Anodonta anatina. Fossil glochidia are potentially powerful tools in the interpretation of palaeoenvironments. Different species of freshwater mussels are known to release glochidia at different times of the year and, therefore, the occurrence of fossil glochidia can provide information on the season during which sediments accumulated. Furthermore, glochidia can provide information on the presence of certain fish species and on water depth. J. Micropalaeontol. 17(2):179-182, December 1998
\end{abstract}

\section{INTRODUCTION}

All unionid mussels produce larval forms known as glochidia, which develop in the modified gill pouches of the female (or hermaphrodite) mussel. Glochidia are obligate parasites on fish, attaching to the gills (in mussels of the genus Unio) and/or the fins (in the genus Anodonta) by spiny valves (Kwon et al., 1993). The glochidium becomes encysted on the host's epithelium and undergoes complete metamorphosis, liquefying the host's tissues to derive nutrients (Baer, 1951). The advantages of such a parasitic strategy appear to be in dispersal, which has led to high phenotypic variability and hence high rates of speciation in the North American Unionidae (Kat, 1984).

The importance of molluscan remains as indicators of nonmarine palaeoenvironments has been widely documented (e.g. Sparks, 1961, 1964; Lozek, 1964). The Unionidae represent a particularly useful tool in palaeoenvironmental reconstructions because they exhibit species-specific preferences for conditions such as rates of water flow, sediment structure, and water depth and chemistry (Ellis, 1962; Ghent et al., 1978; Stone et al., 1982). Unfortunately, the fragmentary nature of most fossil adult unionids (Kennard et al., 1925) makes identification to even the generic level difficult, therefore limiting their palaeoenvironmental value. However, Brodniewicz (1968) described glochidia from Polish Holocene and Pleistocene freshwater deposits which could be reliably assigned to genera. In this study we describe samples of glochidia from British Holocene deposits, which, through comparison with living specimens, can be identified reliably to species level. Fossil glochidia, therefore, may be used to enhance palaeoenvironmental reconstructions by providing detailed information on past water depths, the presence of fish and the seasonality of past sedimentary sequences.

\section{SITE DESCRIPTION AND MATERIAL}

Preserved valves of fossil glochidia were recovered from a $12 \mathrm{~m}$ core of Holocene lake mud and marl, taken from the centre of Quidenham Mere, a small ( $3 \mathrm{ha}$ ), shallow (4 m maximum depth), oval-shaped lake, located $c .10 \mathrm{~km}$ northwest of Diss, on the eastern edge of Breckland in south Norfolk (National Grid Reference TM 040875). The Mere was considerably larger in the early Holocene, and contains a thick, continuous sequence of Holocene peats, lake muds and marls, underlain by Devensian late-glacial clastic sediments. These deposits have been investigated extensively, providing detailed records of the vegetational succession and lake history (Bennett et al., 1990, 1991; Peglar,
1993). Further cores from the lake are currently under investigation for variations in the assemblages of molluscs, ostracods and pollen, and to study mollusc and ostracod shell geochemistry (D. Horne, unpublished data).

The majority of the fossil glochidia picked from Quidenham Mere were found in the top $8 \mathrm{~m}$ of the central core, between 434$1255 \mathrm{~cm}$ (the top $434 \mathrm{~cm}$ includes the water column). This represents a period of sedimentation commencing just after the Elm decline (c. 5000 a BP) and extending up to the present. The presence of fossil glochidia at Quidenham Mere is believed to coincide with a time when the lake was particularly shallow.

\section{METHODS}

Fossil glochidia were observed under a light microscope and their maximum length, width and height (Fig. 1) measured with an eyepiece graticule. Comparisons were made with glochidia removed from living unionids collected from the River Cam, Cambridgeshire.

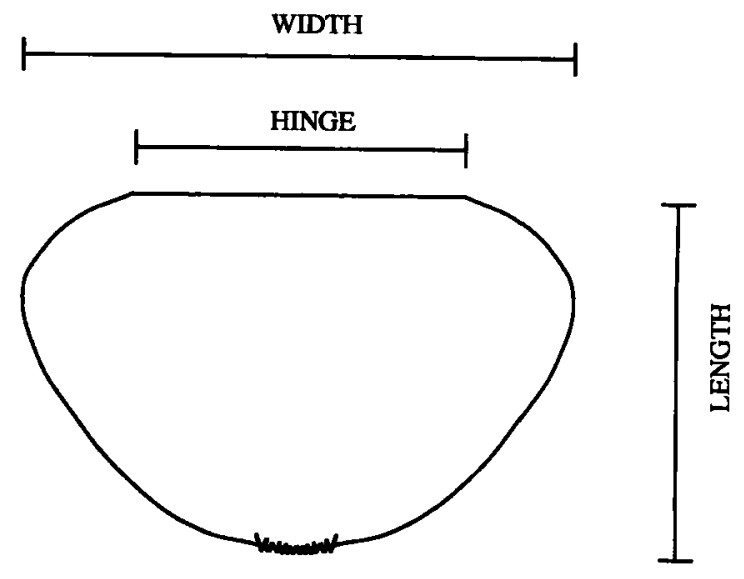

Fig. 1. Morphological characters measured on single valves of glochidia (glochidium shown diagramatically).

\section{RESULTS}

In contrast to the glochidia of living unionids, the two valves of the fossil glochidia were disarticulated and the apical hooks were not preserved (Plate 1). Similar preservation of fossil glochidia was found by Brodniewicz (1968). The fossil glochidia from Quidenham Mere retain the scar of the adductor muscle on the inside of each valve (Pl. 1, fig. 2); this scar is similarly visible in 

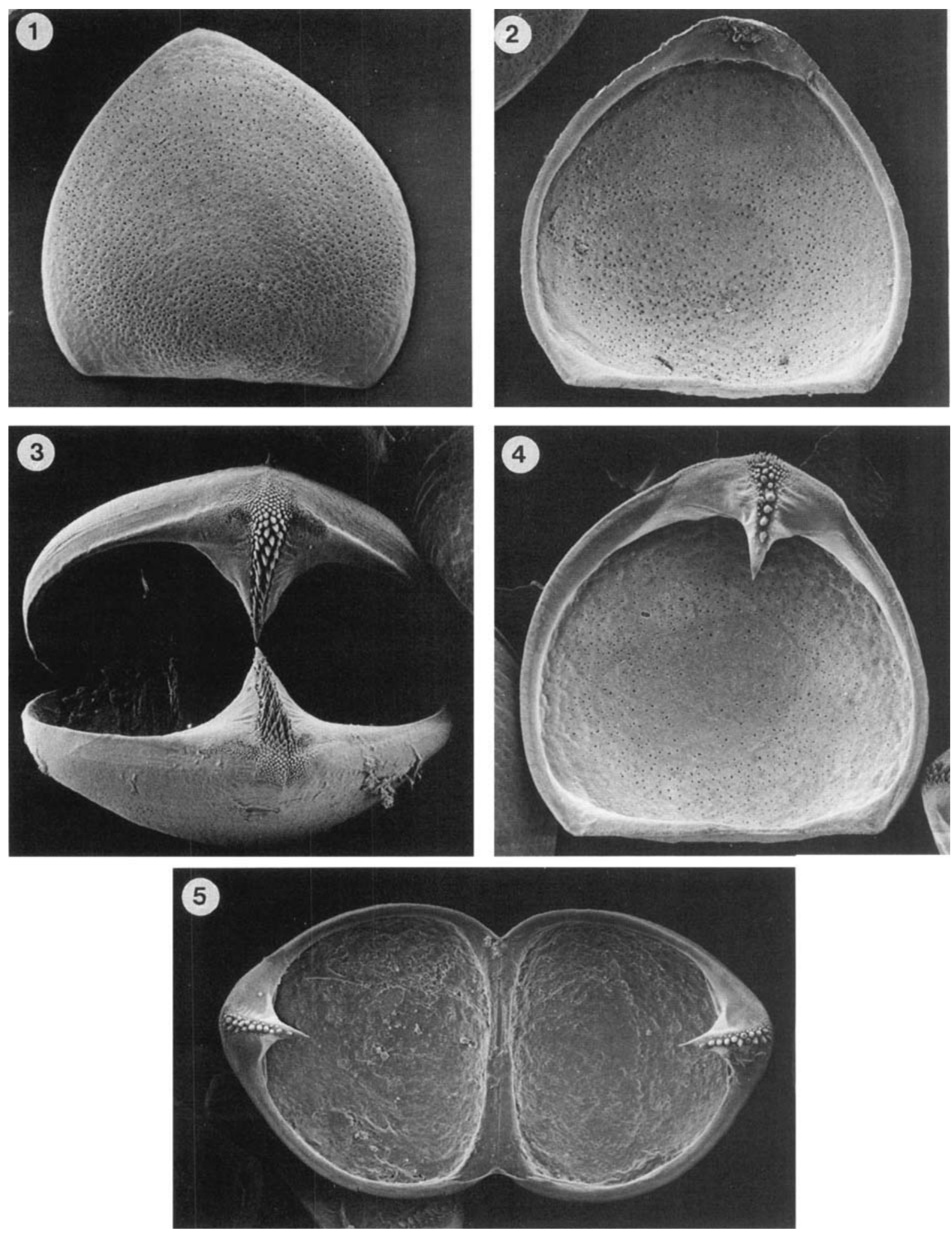

Explanation of Plate 1

Glochidia of fossil and living anodontine unionids. fig. 1, external view of a single valve of fossil Anodonta anatina $\times 170$. 1.24,506. fig. 2, internal view of a single valve of fossil $A$. anatina, showing the dark, oval scar of the adductor muscle $\times 170.1 .24,506$. fig. 3 , entire glochidium of live Pseudanodonta complanata, showing how the apical hooks interlock $\times 180$. I.24,507. fig. 4, internal view of a single valve of live Anodonta cygnea, showing the dark, oval scar of the adductor muscle $\times 200$. I.24,508. fig. 5, entire glochidium of live A. anatina $\times 140.1 .24,509$. All specimens are housed in the mollusc collection of the Museum of Zoology, Cambridge University, Cambridge, UK. 


\begin{tabular}{lllll}
\hline Species & $n$ & $\begin{array}{l}\text { Mean } \\
\text { hook } \\
\text { length }\end{array}$ & $\pm \mathrm{SE}$ & Nature of spines on hook \\
\hline $\begin{array}{l}\text { Anodonta anatina } \\
\text { Anodonta cygnea }\end{array}$ & 30 & 122.0 & $\pm 1.5 \mu \mathrm{m}$ & $\begin{array}{l}\text { Two rows of long spines fringed by smaller spines. Spines do not extend } \\
\text { to the tip of the hook. }\end{array}$ \\
$\begin{array}{l}\text { Single row of few very long, irregularly arranged spines. Spines do not extend } \\
\text { to the tip of the hook. } \\
\text { Many short spines extending to the tip of the hook. }\end{array}$ \\
\hline
\end{tabular}

Table 1. The morphology of the hooks and spines on glochidia of the Anodontinae.

\begin{tabular}{|c|c|c|c|c|c|c|c|}
\hline $\begin{array}{l}\text { Length } \\
\text { Width } \\
\text { Hinge }\end{array}$ & $\begin{array}{l}340.7 \pm 2.4 \\
356.3 \pm 2.0 \\
280.7 \pm 2.1\end{array}$ & $\begin{array}{l}322.2 \pm 1.6 \\
323.7 \pm 1.6 \\
252.3 \pm 1.7\end{array}$ & $\begin{array}{l}342.8 \pm 3.3 \\
402.0 \pm 2.9 \\
306.5 \pm 3.0\end{array}$ & $\begin{array}{l}350.4 \pm 1.3 \\
359.1 \pm 1.3 \\
283.2 \pm 1.3\end{array}$ & $\begin{array}{l}36.1 \\
207.1 \\
88.4\end{array}$ & $\begin{array}{l}3,186 \\
3,186 \\
3,186\end{array}$ & $\begin{array}{l}<0.0001 \\
<0.001 \\
<0.0001\end{array}$ \\
\hline
\end{tabular}

Table 2. Valve measurements of live and fossil glochidia. Mean values and one standard error of the mean are given in $\mu \mathrm{m}$. For live specimens $n=30$, and for fossil glochidia $n=100$.

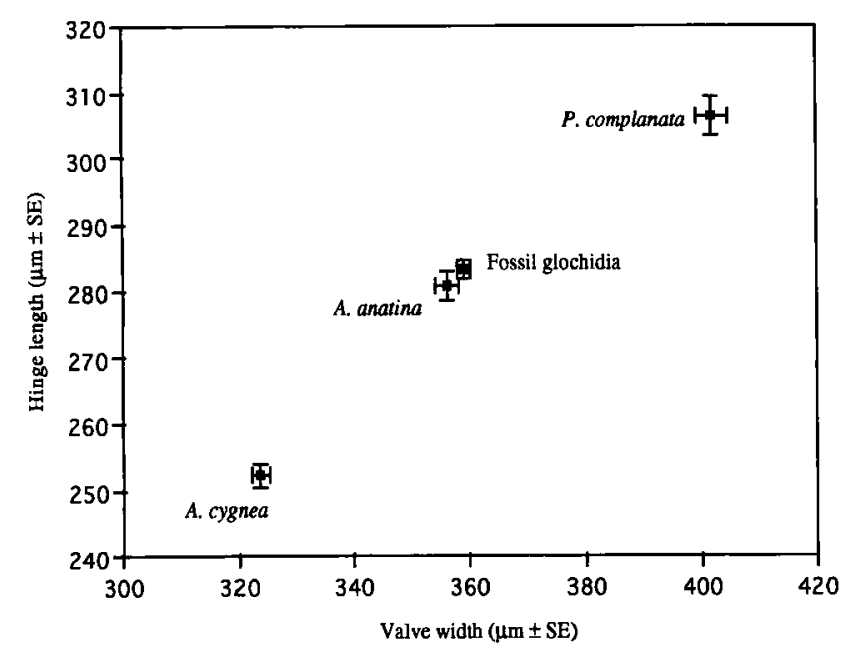

Fig. 2. Valve width and hinge lengths of live and fossil anodontine glochidia.

the glochidia removed from living unionids if the tissue is allowed to decompose (Pl. 1, fig. 4).

It appears that the hooks, which are found only on glochidia of the Anodontinae and not those of the Unioninae, are easily lost following gentle agitation of recently dead glochidia whose tissues have degraded (D. Aldridge, pers. obs.). It is therefore unsurprising that fossil glochidia do not retain their hooks. The preservation potential of detached hooks is unknown, but they can serve as a further tool in determining the species of an anodontine glochidium (Table 1).

All the fossil glochidia from Quidenham Mere can be assigned to the subfamily Anodontinae on the basis of their valve measurements (Table 2). Glochidia of the subfamily Unioninae are only c. $200 \mu \mathrm{m}$ along their longest axis (Wood, 1974). All three valve parameters measured on fossil glochidia approximate to a normal distribution, suggesting that all glochidia belong to the same species.

Comparisons with glochidia removed from live adult Anodontinae indicate that the fossil glochidia are those of Anodonta anatina L. (Table 1; Fig. 2). While ANOVAs show there are interspecific differences in all valve measurements of live and fossil mussels, pair-wise comparisons show that it is only $A$. anatina and the fossil glochidia that have similar valve widths and hinge lengths (Scheffe F-tests give $p>0.05$ ). The valve lengths of the fossil glochidia were significantly different from all the live specimens, and therefore could not be used in the determination of species. This may be a result of hook loss during preservation of fossil glochidia, which could lead to slight changes in valve shape at the apex.

\section{DISCUSSION}

By studying the ecology of living unionids, a number of inferences can be made about the depositional environment at Quidenham Mere during the mid to late Holocene.

\section{Presence of fish}

The reproductive strategy in unionid mussels restricts them to sites which contain fish populations. Glochidia of some unionids have a very narrow range of host species (Kat, 1984) and therefore the presence of glochidia can inform on the presence of certain fish species. Other unionids, such as the Anodontinae, appear to be generalists, metamorphosing on gasterosteids (e.g. three-spined stickleback, Gasterosteus aculeatus), cyprinids (e.g. rudd, Scardinius erythrophthalmus) and percids (e.g. perch, Perca fluviatilis) (Aldridge, in prep.).

Identifiable fossil fish remains, including scales, teeth and vertebrae, were also recovered from the central core. The species composition throughout the core is typical of a still-water community, including predatory species such as pike (Esox lucius) and perch, along with prey species such as roach, rudd, three-spined stickleback, brown trout (Salmo trutta) and eel (Anguilla anguilla) (B. Irving, pers. comm.). Today, the dominant fish species inhabiting the Mere are pike, roach and bream (Abramis brama). Other less common fish include perch, rudd, tench (Tinca tinca), gudgeon (Gobio gobio) and eel (G. Ramm, pers. comm.).

\section{Time of year}

Different species of unionids release glochidia at different times 
of the year (Wood, 1974; Kat, 1984). Therefore, the occurrence of fossil glochidia may provide information on the season during which sediments accumulated. For example, Unio spp. and Pseudanodonta complanata Rossmässler show a relatively short summer reproductive period, with glochidia being released into the water column from May to June, and from June to July respectively. Anodonta spp., on the other hand, release glochidia over a longer period, lasting from December through to March in $A$. anatina and December to April in A. cygnea L. (Aldridge, in press).

Today, Quidenham Mere's unionid population is composed primarily of $A$. cygnea, with smaller numbers of $A$. anatina and Unio pictorum L. Assuming that Unio spp. and Anodonta spp. have co-occurred at Quidenham Mere throughout the Holocene, the absence of the glochidia of Unio spp. in sediments containing glochidia of $A$. anatina suggests that Unio glochidia, and possibly Anodonta glochidia, may disintegrate if they are not quickly subsumed in sediment. Indeed, glochidia removed from live unionids and stored in water for three months become very fragile and break up with gentle agitation (D. Aldridge, pers. obs.). Therefore, it might be interpreted that sediments which contain only $A$. anatina glochidia were formed during a relatively cold (winter or spring) time of year. The absence of $A$. cygnea glochidia associated with those of $A$. anatina may reflect the recent introduction of $A$. cygnea; its widespread distribution is largely a consequence of introduction into ornamental lakes during the 19th century and its subsequent radiation from these sites.

\section{Water depth}

The presence of glochidia in a core provides information on the water depth at that specific site during the time of deposition. It can be assumed that where high densities of glochidia are found within a core, the samples must have been taken in close proximity to adult unionids and represent glochidia that have been unsuccessful in locating a host; glochidia densities would be relatively low in cores where the only glochidia were those sloughed from fish.

The preference of different unionid species for certain water depths and sediment types is widely documented (e.g. Ellis, 1962). A. anatina is generally found to be a shallow water species, inhabiting water depths of up to 3 or $5 \mathrm{~m}$ (Stone et al., 1982; Ökland, 1963), whereas the relatively wide, thin shell of $A$. cygnea enables the animals to rest on the fine sediment-water interface of deeper waters into which $A$. anatina would sink (Ghent et al., 1978). Müller \& Patzner (1996) recorded A. cygnea at depths of $7 \mathrm{~m}$, and the wide, thin-shelled $A$. grandis has been recorded at depths of $14 \mathrm{~m}$ (Ghent et al., 1978). Where water bodies are subject to stratification, unionids will be found only above the oxycline.

\section{CONCLUSIONS}

Fossil glochidia identified to species level have considerable potential in the detailed interpretation of past depositional environments. In particular, they can provide information on the presence of fish, seasonality of sedimentary sequences and water depth. For example, it can be deduced that the sediments from Quidenham Mere in which we found fossil glochidia were not formed during the summer (due to the absence of Unio spp. glochidia) and formed at a depth of less than $5 \mathrm{~m}$ (due to the presence of $A$. anatina glochidia). It is highly probable that glochidia are preserved more widely than has been documented to date, but that previously they have been overlooked. A test of the utility of fossil glochidia would be to find glochidia of summer-releasing species preserved in the summer laminations of varved sediments, and those of winter-releasing species preserved in the winter laminations. This would provide more robust evidence of seasonal deposition in sedimentary sequences.

\section{ACKNOWLEDGEMENTS}

We would like to thank Richard Preece and Dick Aldridge for helpful comments and suggestions on the manuscript, Bill Lee for technical help on the electron microscope and Brian Irving for kindly identifying fossil fish remains. Permission to work at the field site was kindly given by Graham Ramm of Quidenham Mere Angling Association and Eagle Star Insurance. This research was supported by a BBSRC studentship to D. Aldridge and a NERC studentship to D. Horne.

\section{REFERENCES}

Aldridge, D. C. in press. The morphology, growth and reproduction of Unionidae (Bivalvia) in a Fenland waterway. Journal of Molluscan Studies.

Baer, J. G. 1951. Mollusca. In Baer, J. G. (Ed.), Ecology of Animal Parasites, pp. 20-22. University Press, Illinois, USA

Bennett, K. D., Simonson, W. D. \& Peglar, S. M. 1990. Fire and man in postglacial woodlands of eastern England. Journal of Archaeological Science, 17: 635-642.

Bennett, K. D., Peglar, S. M. \& Harp, M. J. 1991. Holocene lake sediments in central East Anglia. In Lewis, S. G., Whiteman, C. A. \& Brigland, D. R. (Eds), Central East Anglia \& The Fen Basin, pp. 111-118. Quaternary Research Association, London, UK.

Brodniewicz, I. 1968. On glochidia of the genera Unio and Anodonta from their Quaternary fresh-water sediments of Poland. Acta Palaeontologica Polonica, 13: 619-627.

Ellis, A. E. 1962. British Freshwater Bivalve Molluscs. Synopses of the British Fauna No. 13, The Linnean Society of London, UK.

Ghent, A. W., Singer, R. \& Johnson-Singer, L. 1978. Depth distributions determined with SCUBA, and associated studies of the freshwater unionid clams Elliptio complanata and Anodonta grandis in Lake Bernard, Ontario. Canadian Journal of Zoology, 56: 1654-1663.

Kat, P. W. 1984. Parasitism and the Unionacea (Bivalvia). Biological Reviews of the Cambridge Philosophical Society, 59: 189-207.

Kennard, A. S., Salisbury, A. E. \& Woodward, B. B. 1925. Notes on the British post-Pliocene Unionidae with more especial regard to the means of identification of fossil fragments. Proceedings of the Malacological Society of London, 16: 267-285.

Kwon, O.-K., Park, G.-B., Lee, J.-S. \& Song, H.-B. 1993. Scanning electron microscope studies of the minute shell structure of glochidia of three species of Unionidae (Bivalvia) from Korea. Malacological Review, 26: 6370.

Lozek, V. 1964. Quartärmollusken der Tschechoslowakei. Rozpravy, Ustredniho ústavu geologického, Suazek 31, Verlag der Tschechoslowakischen Akademie der Wissenschaften.

Müller, D. \& Patzner, R. A. 1996. Growth and age structure of the swan mussel Anodonta cygnea (L.) at different depths in lake Mattsee (Salzburg, Austria). Hydrobiologia, 341: 65-70.

Ökland, J. 1963. Notes on population density, age distribution, growth and habitat of Anodonta piscinalis Nilss. (Moll., Lamellibr.) in a eutrophic Norwegian lake. Nytt magasin for zoologi, Oslo, 11: 19-43.

Peglar, S. M. 1993. Mid- and late- Holocene vegetation history of Quidenham Mere, Norfolk, UK, interpreted using recurrent groups of taxa. Vegetation History and Achaeobotany, 2: 15-28.

Sparks, B. W. 1961. The ecological interpretation of Quaternary non-marine Mollusca. Proceedings of the Linnean Society of London, 172: 71-80.

Sparks, B. W. 1964. Non-marine Mollusca and Quaternary ecology. Journal of Animal Ecology, 33: 87-98.

Stone, N. M., Earll, R. Hodgson, A. \& Mather, J. G. 1982. The distributions of three sympatric mussel species (Bivalvia: Unionidae) in Budworth Mere, Cheshire. Journal of Molluscan Studies, 48: 266-274

Wood, E. M. 1974. Development and morphology of the glochidium larva of Anodonta cygnea (Mollusca: Bivalvia). Journal of Zoology, London, 173: 114. 